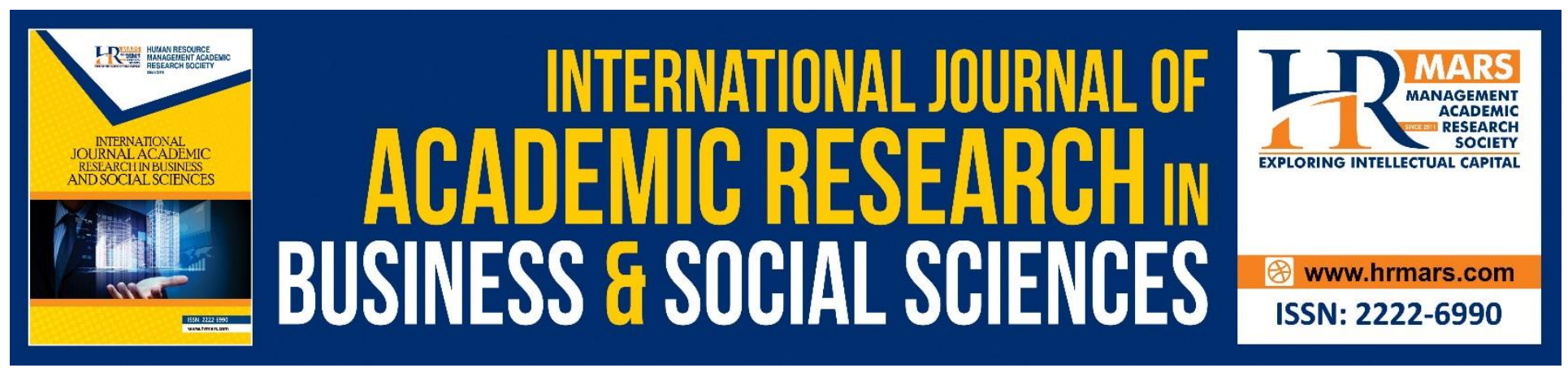

\title{
The Impact of the IT Determinants on the Extent Use of E- HRM: Exploratory study for the internet service providers (ISP) in Egypt
}

\section{Kamel Omran, Noha Anan}

To Link this Article: http://dx.doi.org/10.6007/IJARBSS/v9-i3/5754

DOI: $\quad 10.6007 /$ IJARBSS/v9-i3/5510

Received: 02 Feb 2019, Revised: 17 Feb 2019, Accepted: 30 Feb 2019

Published Online: 03 March 2019

In-Text Citation: (Omran \& Anan, 2019)

To Cite this Article: Omran, K., \& Anan, N. (2019). The Impact of the IT Determinants on the Extent Use of E-HRM: Exploratory study for the internet service providers (ISP) in Egypt. International Journal of Academic Research in Business and Social Sciences, 9(3), 902-923.

\section{Copyright: (C) 2019 The Author(s)}

Published by Human Resource Management Academic Research Society (www.hrmars.com)

This article is published under the Creative Commons Attribution (CC BY 4.0) license. Anyone may reproduce, distribute, translate and create derivative works of this article (for both commercial and non-commercial purposes), subject to full attribution to the original publication and authors. The full terms of this license may be seen at: http://creativecommons.org/licences/by/4.0/legalcode

\section{Vol. 9, No. 3, 2019, Pg. 902 - 923}

Full Terms \& Conditions of access and use can be found at http://hrmars.com/index.php/pages/detail/publication-ethics 


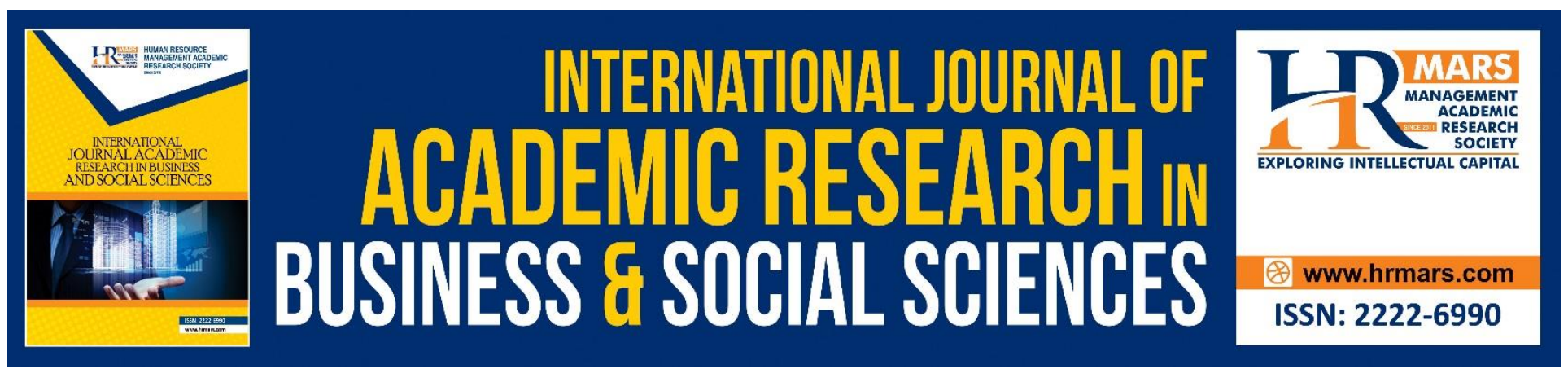

\title{
The Impact of the IT Determinants on the Extent Use of E-HRM: Exploratory study for the internet service providers (ISP) in Egypt
}

\author{
Kamel Omran ${ }^{1}$, Noha Anan ${ }^{2}$ \\ ${ }^{1}$ Professor of Human Resource Management, Business administration department, Faculty of \\ Commerce, Cairo University, Egypt., \\ 2 Professor of Human Resource Management, Business administration department, Faculty of \\ Commerce, Cairo University, Egypt.
}

Email: nohaanan@yahoo.com

\begin{abstract}
The role of HRM has changed altogether from a traditional (popularly called personnel management) to a strategic one. Most medium and large scale organizations spend large amounts of money and reserves on HR software, but unfortunately many of them utilize it only for HR administrative purposes rather than for effective and efficient human resource management. Closing the HRM technology gap has significant long-term benefits to the organization, above and beyond the support it can provide to HRM. To this end, the crucial first step is to understand the different perspectives in HRM, and the interactions among these perspectives. By perspective is meant a particular view of information, which leads to a particular set of decisions over the information.

This study aims to investigate the impact of the IT determinants of adopting E-HRM on the extent use of E-HRM in Egyptian organizations and the advantages they derive from the implementation of the same in the Human Resource Management (HRM) functions. Primary data was collected by means of questionnaires from 128 senior and junior HR executives/managers in four organizations in Egypt. It was found that the greatest determinants of E-HRM has its impact on the extent use of E-HRM that in turn has its impact on the effectiveness and efficiency of the whole organization.
\end{abstract}

Keywords: Human Resource Management, Relative Advantage, Complexity, Compatibility, Trailability

\section{Introduction}

Significant advancements in technology continue to free HR from the administrative role, providing more opportunity to focus on strategy. Increasingly uniform standards for systems language are being created, in large part, to enable companies to "plug and play" without major systems conversions. Even small companies could access sophisticated HR solutions through such developments. 
Existing and developing technologies will dramatically change the way HR work is done. These technologies will change the structure of HR's interface with employees, bring a high degree of choice and self-service to employee transactions, and create a different venue for training and development. The opportunity to outsource will fundamentally change the structure and purpose of an "internal" HR function. A particularly critical change will be the delivery system for training, with an almost total shift to online or e-Learning available to employees. A selection of new technologies that are sure to impact HR include: ASPs and technology outsourcing, Voice recognition, e-Learning, Virtual shared service centers, Web portals, Streaming desk-top video, Mobile web, E-signatures.

\section{Problem Definition}

In this paper, the researcher presents the results of a quantitative study on the question whether the IT determinants has an impact on the extent use of E-HRM or not using census studies. It draws on data from multiple sources. This was carried out in the internet service providers (ISPs) companies in Egypt.

Thus, the problem of this study can be identified in a key research question, which is: "What is the impact of IT determinants of adopting E-HRM technology on the extent use of E-HRM?

\section{Research Objectives}

The objective of the present study attempts to investigate the determinants of the adoption of the E-HRM technology in (ISPs) Egyptian firms, thus developing a conceptual model based on TAM in order to predict user acceptance of E-HRM system in (ISPs) firms in Egypt.

\section{Research Importance}

Technology use has been the subject of much research in the past few decades. Since the 1970s, there has been a shift in focus to identifying conditions or factors that facilitate technology integration in organizations. In the Information Age, the advent of computers and the Internet has increased the impact of the importance of technology significantly. Many businesses cannot even function without the use of computer technology. This impact is seen in nearly all areas of business, including human resources, where technology continues to have a significant impact on HR practices. The success of a business is directly linked to the performance of those who work for that business. Underachievement can be a result of workplace failures.

This paper provides a detailed outline of how some determinants have their impact on adopting new innovation (E-HRM technology) on the role of the HRM in Egyptian firms attempting to fill the gap in IT and E-HRM literature especially in developing countries such as Egypt.

\section{Literature Review}

\section{Previous studies on E-HRM}

Previous studies on E-HRM have been conducted by researchers in developed countries as USA and Europe so, there should be a considerable difference in research results on E-HRM because of the huge difference in the market environment and management mechanisms between developed countries and Egypt as a developing country. However, the researcher has listed some previous researches related to the research variables. 
Stirpe \& Bonache (2015) studied the effect of two forms of support on the acceptance of newly introduced HR practices (NHRPs): that of top managers and of supervisors. In addition, the authors analyzed how these two forms of support work in conjunction with one another. The authors argued that a lack of consistency between the two impairs NHRP acceptance. The authors also explored variations in acceptance under different organizational climates. The analysis is based on an original sample of 307 employees from nine multinational companies operating in Spain. The authors found that top management support, supervisor support, and innovation climate are all predictors of NHRP acceptance. The authors also found that low supervisor support reduces the effect of top management support. Finally, the authors found that innovation climate is not a substitute for management and supervisor support.

Jain \& Goyal (2014), studied what all E-Recruitment strategies are used by the organizations in India after being globalized. The study has been made in some of the reputed banks of India. This study has been conducted in Jaipur city; the study identifies the overall processes and methods of erecruitments, it also studied whether it's challenging for the manager and relevant advantages \& limitation of E-Recruitment.

Nagendra \& Deshpande (2013) studied the extent of usage of a Human Resource Information System (HRIS) in mid to large sized organizations and the advantages they derive from the implementation of the same in the Human Resource Planning (HRP) sub-functions. HRIS outline the integration between Human Resource Management (HRM) and Information technology from 50 senior and junior HR executives/managers in three organizations in Pune.

The study revealed that HRIS needs to offer more intelligent capabilities to increase the effectiveness of HR planning.

Laumer, Eckhardt \& Weitzel (2010) studied E-HRM in an E-Business environment among 144 HR managers from Germany's top 1,000 firms. Their survey results revealed that HR managers' most pressing challenges are staff retention and internal and external employer branding. They stressed the importance of devising an E-HRM that is both effective, i.e. adequately fills vacancies, and efficient, i.e. makes best use of scarce resources.

Strohmeier \& Kabst (2009) examined the factors that influenced the cross-national organizational adoption of E-HRM in Europe. Major general and contextual influence factors were derived and tested by means of logistic regression in a large-scale survey with a sample of 2,336 organizations in 23 European countries. They revealed that E-HRM is a common practice throughout Europe since two thirds of all organizations have already adopted E-HRM. They also found that major determinants of E-HRM adoption are size, work organization, and configuration of HRM.

Voermans \& Veldhoven (2007) conducted a study on attitude towards E-HRM. They utilized an online questionnaire, in which 99 managers and 257 employees within Philips (Electronics) Netherlands participated. They found that differences in perceived usability of current IT systems, as well as the 
INTERNATIONAL JOURNAL OF ACADEMIC RESEARCH IN BUSINESS AND SOCIAL SCIENCES

Vol. 9, No. 3, March, 2019, E-ISSN: 222 2-6990 (C) 2019 HRMARS

preferred HR roles of strategic partner (high preference) and employee champion (low preference), were related to a positive attitude towards E-HRM systems. For managers, user support was also found to be a predictor of a positive attitude towards E-HRM.

Lujan, Raminez \& Cantu (2007) conducted a case-based study in order to investigate how four of the most competitive Mexican firms are implementing their E-HRM strategy. They discovered that to fully understand the way E-HRM is used in firms from emerging economies, it is important to take into consideration local idiosyncrasies.

\section{HRM and Technology}

The dynamic nature of technology has contributed to the existence of various definitions and concepts of technology (Wahab et al., 2012). The discussion on the concept of technology is crucial in getting a clear understanding of the nature of technology and examining what the technology consists of.

The term 'technology' is inherently abstract concept which is difficult to interpret, observe and evaluate (Wahab et al., 2012). Regardless of the extensive research done on this subject, many of the literatures are fragmented along different specialties and generally there is no commonly accepted paradigm (Wahab et al., 2012). Technology represents the combination of human understanding of natural laws and phenomena accumulated since ancient times to make things that fulfil our needs and desires or that perform certain functions. (Aunger, 2010) defined technology as "a body of knowledge used to create tools, develop skills, and extract or collect materials".

The UN Conference on Trade and Development (UNCTAD) has provided the following definition:

Technology is bought and sold as capital goods including machinery and productive systems, human labor usually skilled manpower, management and specialized scientists, information of both technical and commercial character, including that which is readily available, and that subject to proprietary rights and restrictions. (Li-Hua \& Lu, 2013)

Limiting technology to science, engineering and mathematics loses sight of other supporting technologies. Actually, technology includes more than machines, processes and inventions. Traditionally, it might concentrate more on hardware; however, these days it concentrates more on the soft side as well. Technology refers to the theoretical and practical knowledge, skills and artefacts that can be used to develop products and services as well as production and delivery systems.

Technology is considered to be embodied in people, materials, cognitive and physical processes, plant, equipment and tools (Li-Hua \& Lu, 2013). Furthermore, knowledge transfer/knowledge sharing has been widely recognized to be strategically significant for international collaboration. Without knowledge transfer, technology transfer does not take place in international joint venture projects; therefore, knowledge transfer is a strategic issue when addressing issues of technology management. Technique and knowledge must be organized before they can bring results. Organization of a working process of technique and knowledge is, therefore, an integral part of technology. The ultimate purpose of bringing technique, knowledge and organization together is, of course, to obtain a product. Without including this goal, it is in fact, difficult to understand the other three elements properly. 


\section{Information Technology in HRM}

The most salient factor impacting organizations and employees today is technological change. This can be seen in areas such as computer-supported work at-home, overall changes in labor force skills, and changes in organizational structure and organization of work. Information technology (IT) has grown substantially in recent years and driven much of this change. Roach (1991) as cited by (Normalini et al,2012) found that in 1991 American service sector companies spent more than $\$ 100$ billion on hardware and in 1996 American banks spent almost \$18 billion on IT (The Economist, 1996) as cited by (Normalini et al,2012). One implication is that the nature of work is likely to shift as IT has the potential to change the roles of employees within the organization.

Recent studies have examined determinants of HRIS adoption in Singapore (Teo et al., 2007) and the degree to which HRIS can enable strategic focus of HR. (Normalini et al, 2012), the adoption of HRIS in the public sector depends on environmental, organizational and technology context factors.

The need for efficient and effective performance management systems (PMS) has increased over the last decade. The use of PMS has improved the performance and overall quality of an organization (Normalini et al, 2012). According to (Normalini et al,2012), many smaller companies already use service providers for HR-related systems such as payroll, and training departments are rapidly utilizing online classes as well as video technology. With this growth in IT utilization, practitioners and researchers alike recognize that IT may have a tremendous impact on the different functions, including $\mathrm{HR}$, and individuals in the organization (Gardner et al., 2003) as cited by (Normalini et al,2012).

Ulrich (1997) as cited by (Normalini et al, 2012), for instance, has argued that, "technology will change how work is done in general and how HR (human resources) is practiced in particular." As the human resource management function increases its use of IT, there are likely to be implications for HR professionals as well. As more HR professionals are able to be more responsive, answer queries more quickly, and provide more accurate information, HRIS may enable HR professionals to increase their responsiveness to their constituencies. Information technology has followed evolutionary trends from human resource information system (HRIS) to electronic human resource management (e-HRM) as such; a distinction should be made between them as follows;

\section{The Relation between Human Resource Information System (HRIS) and e-HRM:}

The distinction between e-HRM and HRIS is that a HRIS tends to be limited and affects only those individuals working in or with the organization's HR function. In addition, HRIS is an older concept, pre-dating the emergence of networking and internet-based communications technology.

In contrast, e-HRM represents an internet-based information technology that reaches all employees, at all levels within an organization. Thus, we consider HRIS to be part of e-HRM to the extent it includes internet-based information technology; however, e-HRM is a broader construct in that it is not limited to individuals or processes attached to the HR function within an organization. 
E-HRM consists of configurations of: computer hardware, software, and electronic networking resources that enable intended or actual HRM activities (e.g., policies, practices, and services) through individual and group-level interactions within and across organizational boundaries.

\section{Definitions and Evolution of e-HRM}

The term e-HR was first used in the 1990"s and refers to conducting Human Resource Management "transactions" using the internet or an intranet. The term was inspired by the popular term of ecommerce, and wrongfully adopted the "e-" prefix, signifying "electronic", even if e-HR is very specific to the use of the Net, so that a more accurate term would be "online HRM".

E-HRM consists of configurations of: computer hardware, software, and electronic networking resources that enable intended or actual HRM activities (e.g., policies, practices, and services) through individual and group-level interactions within and across organizational boundaries.

Some definitions see e-HRM as conducting HR transactions using the Internet or intranet and consequently the value created by e-HRM would likely be assessed as improvement of the administrative HR processes. According to (Bondarouk \& Ruel, 2004) e-HRM is defined as: "an umbrella term covering all possible integration mechanisms and contents between HRM and Information Technologies aiming at creating value within and across organizations for targeted employees and management."

This definition suggests an integration of four aspects: content of e-HRM (concerns any type of HR practices that can be supported with IT), implementation of -HRM (involves the process of adoption and appropriation of e-HRM by organizational members), targeted employees and managers (thousands of people are zipping around the Internet in search of employment opportunities, forcing organizations to direct e-HRM effort towards potential candidates), and finally e-HRM consequences (the monetary amount exchanged must exceed the producer's costs (time, training, effort, money, meetings dedicated to e-HRM projects); and it is approximated as a delta between new value (like freedom from HR administration or less paper work) and the users" alternative).

In the mid of 1990s the World Wide Web (Web) emerged as a means of facilitating two-way communication and instant worldwide information over the Internet.

Toward the end of the 1990s, the migration to Web-enabled systems began, and companies started developing HR software that would be compatible with Internet architecture. In the early 2000s, this new software enabled the centralization of all HR and organizational data so that users could access it through Web browsers at any time or place. Organizations then began using Web-based technology to interact with both internal and external stakeholders (e.g., job applicants, employees, managers, benefit and payroll providers, etc.). For instance, these systems enabled organizations to develop Web-based recruiting systems that could be used to attract applicants anywhere in the world, and allow them to apply for jobs online. It was at this time that these systems became known as electronic human resource information systems (e-HRM) because they enabled HR transactions through the Internet. The new e-HRM systems facilitated and modified a number of HR processes including job analysis, recruitment, selection, training, compensation, performance management and HR planning. 
INTERNATIONAL JOURNAL OF ACADEMIC RESEARCH IN BUSINESS AND SOCIAL SCIENCES

Vol. 9, No. 3, March, 2019, E-ISSN: 222 2-6990 ¿ 2019 HRMARS

So, there is no standardized definition of e-HRM yet. Different perspectives (IT and HR) fall under a common label, despite there being no common terminology set in which to create and test ideas, constructs, or concepts.

\section{Impact of Information Technology on HRM}

Technology is having a profound effect on human resource management (HRM) and is propelling them in some entirely new directions as follows;

\section{1) The impact of technology on professional HR competence}

There are four-dimensional model in this area:

a. Knowledge of the business. Knowledge of the business refers to the extent to which an HR professional understands the financial, strategic, and technological capabilities of an organization. It include the ability to align HR strategies with business vision and the ability to consult with line management to analyze and solve problems.

b. Delivery of HR practices. Competence in this area refers to "knowing and being able to deliver innovative HR practices.

c. Change management. HR professionals who have the capacity to manage change are able to "increase an organization's capability for change through creating meaning, problem solving, relationship influence, innovation, transformation, and role influence.

d. Technology expertise. Varying degrees of technological ability of HR professionals also are generally required.

Thus, HR professionals need to be able to use HR technology and web-based channels to deliver services to employees. HR professionals must often be capable of using technology to collect data and transform it into strategically valuable information. HR professionals are increasingly being tasked with helping to identify technology needs, managing technology vendors, and mobilizing technologies to support and evaluate the HR function, all of which require technology competence, in order to do so, they have to acquire some basic skills such as follows:

There are five critical skill categories:

Business Skills-HR professionals must understand the dynamics of business and possess the financial acumen to assess and communicate how HR strategies impact the bottom line. Project and process management skills also fall within this broad category. Leadership skills-HR professionals must have the ability to create a vision and strategy and to ensure the alignment of the organization with the strategy and the ability to manage and motivate a team. Consulting skills-Truly effective HR professionals develop their consulting skills, with a focus on the ability to market their work within the organization. Cultivating an executive presence through progressive experience working with senior business leaders is also important. Technology skills-HR professionals must develop a proficiency in broad HR applications and their potential delivery systems. They must be able to apply this knowledge to the business-planning process. Global mindset-Business is increasingly global, 
INTERNATIONAL JOURNAL OF ACADEMIC RESEARCH IN BUSINESS AND SOCIAL SCIENCES

Vol. 9, No. 3, March, 2019, E-ISSN: $2222-6990$ C 2019 HRMARS

requiring $H R$ to understand the dynamics of the global marketplace. HR leaders should cultivate a staff that is multi-lingual and has direct experience working in other cultures.

\section{Impact of Technology on HR practices}

E-HR can have an impact on every area of HRM, the effects of technology on six key HR processes: (Panayotopoulou, Vakola \& Galanaki, 2007)

(1) HR planning;

(2) Acquiring HR (recruitment and selection);

(3) HR evaluation (performance appraisal);

(4) Communication;

(5) Rewarding HR (performance appraisal, compensation and benefits); and

(6) Developing HR (training and development, career management).

Firms today realize that innovative and creative employees who hold the key to organizational knowledge provide a sustainable competitive advantage because unlike other resources, intellectual capital is difficult to imitate by competitors. Organizational resources related to materials, equipment, technology, finances etc. have proved short lived in the absence of human capital capable of deploying these resources effectively and efficiently.

Accordingly, the people management function has become strategic in its importance and outlook and is geared to attract, retain, and engage talent. These developments have added emphasis on the return on investment (ROI) of the HR function and its programs. Finally, human resources can be viewed as non-substitutable due to their potential to withstand the time test of becoming obsolete and ability to be transferred across technologies, products, or

markets.

\section{Types of Human Resources Systems}

There are some Human Resources software programs that have arisen recently to help HR managers doing their work and solving some problems they usually face in work. These programs are shown in the next table.

Table (1): Types of Human Resources Systems

\begin{tabular}{|l|l|}
\hline $\begin{array}{l}\text { Human Resources } \\
\text { software programs }\end{array}$ & Descriptions \\
\hline Bamboo HR & $\begin{array}{l}\text { Bamboo HR is a Web-based human resources (HR) software solution } \\
\text { that is well-suited for small to midsized businesses, and as it's Web- } \\
\text { based, Bamboo HR is accessible through the Web browser of any device } \\
\text { with an Internet connection. }\end{array}$ \\
\hline HRM Direct & $\begin{array}{l}\text { HRM Direct is recommend for organizations with 100 to 5,000 } \\
\text { employees in a variety of different industries. This solution is a good fit } \\
\text { for companies that want to improve recruitment, on boarding and new } \\
\text { talent management. }\end{array}$ \\
\hline
\end{tabular}




\begin{tabular}{|c|c|}
\hline The Resumator & $\begin{array}{l}\text { This browser-based system uses social recruitment applications to } \\
\text { organize and automate recruiting processes through networks like } \\
\text { Facebook and LinkedIn. The Resumator is highly customizable. }\end{array}$ \\
\hline $\begin{array}{l}\text { The Applicant } \\
\text { Manager }\end{array}$ & $\begin{array}{l}\text { The Applicant Manager (TAM) offers human resources software } \\
\text { designed specifically for the first step in the employee life cycle: hiring. } \\
\text { With TAM, recruiters can track communication with candidates and } \\
\text { schedule interviews. }\end{array}$ \\
\hline iCIMS Talent Platform & $\begin{array}{l}\text { iCIMS is a top-ranked, award-winning platform for retention and } \\
\text { customer satisfaction. The tool is a good option for companies of all sizes } \\
\text { and has extensive talent recruiting and management features. }\end{array}$ \\
\hline $\begin{array}{l}\text { Kronos Workforce } \\
\text { Ready Workforce }\end{array}$ & $\begin{array}{l}\text { Ready is a cloud-based solution offering a variety of modules that allows } \\
\text { you to custom a system for employee data management. The solution } \\
\text { offers a robust workflow engine and reporting, and also a mobile } \\
\text { application. }\end{array}$ \\
\hline Ascentis & $\begin{array}{l}\text { Ascentis is a fully integrated human resources software suite, which } \\
\text { includes applications that span the employee life cycle, including } \\
\text { recruiting, performance reviews, as well as personnel tracking and } \\
\text { benefits administration. }\end{array}$ \\
\hline Tribe HR & $\begin{array}{l}\text { Tribe HR is intuitive and affordable software for HR professionals, } \\
\text { offering stand-alone applicant tracking, and recruiting \& performance } \\
\text { review modules, among others. It is recommended for companies with } \\
\text { fewer than } 250 \text { employees. }\end{array}$ \\
\hline $\begin{array}{l}\text { Halogen } \quad \text { Talent } \\
\text { Management Suite }\end{array}$ & $\begin{array}{l}\text { Halogen offers a comprehensive suite of software solutions designed to } \\
\text { support optimal employee performance from hire to retire. Named a } \\
\text { market leader by Gartner, Halogen has been creating powerful solutions } \\
\text { for over } 10 \text { years. }\end{array}$ \\
\hline iRecruit & $\begin{array}{l}\text { iRecruit is a cloud-based recruiting solution designed to help } \\
\text { organizations of all sizes streamline and automate the applicant tracking } \\
\text { process. With iRecruit, companies can centralize and simplify their } \\
\text { recruiting program. }\end{array}$ \\
\hline
\end{tabular}




\section{Methodology}

\section{Research Hypotheses}

\section{The research Hypotheses are}

Past research has indicated that innovation with substantial complexity requires more technical skills and needs greater implementation and operational effort to increase its chances of adoption according to (Normalini et al, 2011). As with any other new computing system introduced to the market, E-HRM is expected to be easy to use. It is therefore expected that the less complex to use EHRM is perceived to be, the more likely it is for an individual to adopt it. This leads to the next hypothesis:

\section{H1. Perceived complexity has a strong negative impact on extent of E-HRM use.}

(Rogers, 2003) argues that potential adopters who are allowed to experiment with an innovation will feel more comfortable with the innovation and are more likely to adopt it. According to (Normalini et al, 2011) stated that the more adopters experiment with a new technology and explore its ramifications, the greater the likelihood that the innovation will be used during early stages of adoption. Any uncertainties about the innovation will also be reduced when trials are allowed. Thus, this becomes the basis of hypothesis four in this study which is stated as:

\section{H2. Perceived trialability has a strong positive impact on extent of E-HRM use.}

The suggestion that a new product should be trialed before it is purchased or adopted was introduced by (Normalini et al, 2011). Trialability is a form of partial adoption and as such is treated as a proxy of behavioral intent. An innovation that can be tested by a consumer in their own conditions (high trialability) is more likely to be adopted than an innovation that does not have trialability.

From literature, innovation is more likely to be adopted when it is compatible with an individual's job responsibilities and value system. Previous empirical studies found positive relationship between compatibility and intention to use. Thus, the next hypothesis is stated as:

\section{H3. Perceived compatibility has a strong positive impact on extent of E-HRM use.}

Researchers found relative advantage to be an important factor in determining adoption of new innovations. Previous researches have indicated that perceived usefulness/relative advantage is positively related to system usage. This leads to the following hypothesis:

H4. Perceived relative advantage has a strong positive impact on extent of E-HRM use.

\section{Research Measures}

Multi-item scales from Unified Theory of Acceptance and Use of Technology (UTAUT) instruments were adapted to measure the variables on a seven-point Likert-type scale where 1=strongly disagree and $5=$ strongly agree. Five items measuring attitude towards using E-HRM, In addition the instrument included: three questions for this part of the research which were modified and adapted from the questionnaire in (Maatman, 2010) on the clarity of E-HRM technology; three items on user satisfaction adapted from; four items measuring perceived usefulness; five items for perceived ease of use adapted from (Davis, 1989); and two items measuring user support. All the scale items were modified for testing in the E-HRM context. 


\section{The Proposed Research Model}

Predicting user acceptance of technology, systems, and service has been an important topic in both industry and academic studies for several decades. As new technologies are being consistently developed and introduced, numerous theoretical models have been proposed to predict user perceptions of these technologies.

In this model, individual perceptions of the E-HRM technology represent the primary antecedents of E-HRM acceptance. This aspect of our model is consistent with the most widely cited and empirically tested technology acceptance model (TAM) in the information sciences. In addition, the current model introduces several key individual, organizational, and technological characteristics, which argue also significantly influence individual perceptions of E-HRM technology. By focusing on these characteristics and their impact on E-HRM technology acceptance, the model enriches current models of technology acceptance and better clarifies how organizations can effectively manage $E$ HRM implementations.

Given the success of TAM in predicting user acceptance of a newly introduced technology, the present study develops a conceptual model based on TAM in order to predict user acceptance of EHRM system.

\section{The E-HRM Acceptance Model}

The model is based on technology acceptance as it relates to the initial decision to use or adopt a new technology. An individual's decision to first use a technology is different from the decision to continue to use a technology. Perceived ease of use is intentionally excluded from the proposed model because previous studies, in particular on user acceptance of mobile and internet technologies, have suggested that perceived ease of use often diminishes the compatibility and complexity of a research model.

In addition to the two constructs from the original TAM, the present study examines two external variables (i.e. perceived relative advantage and perceived trialability) that are likely to have significant effects on user perceptions of and attitudes toward E-HRM system.

The TAM posits two antecedents, perceived usefulness and perceived ease of use, as determinants of attitude. As per the established TAM, the belief that E-HRM technology is easy to use it will be positively associated with HR professionals' attitude toward using it. If E-HRM is considered effortless to use, HR professionals are likely to think that E-HRM will let them utilized the technology more efficiently and effectively. Recent studies have found that ease of use and usefulness were associated with attitude toward using technology. 
INTERNATIONAL JOURNAL OF ACADEMIC RESEARCH IN BUSINESS AND SOCIAL SCIENCES

Vol. 9, No. 3, March, 2019, E-ISSN: $2222-6990$ C 2019 HRMARS

The research hypotheses can be represented by the following model figure (1)

A-Independent variables: IT Determinants of adopting E-HRM

B-Dependent variables: The extent use of E-HRM

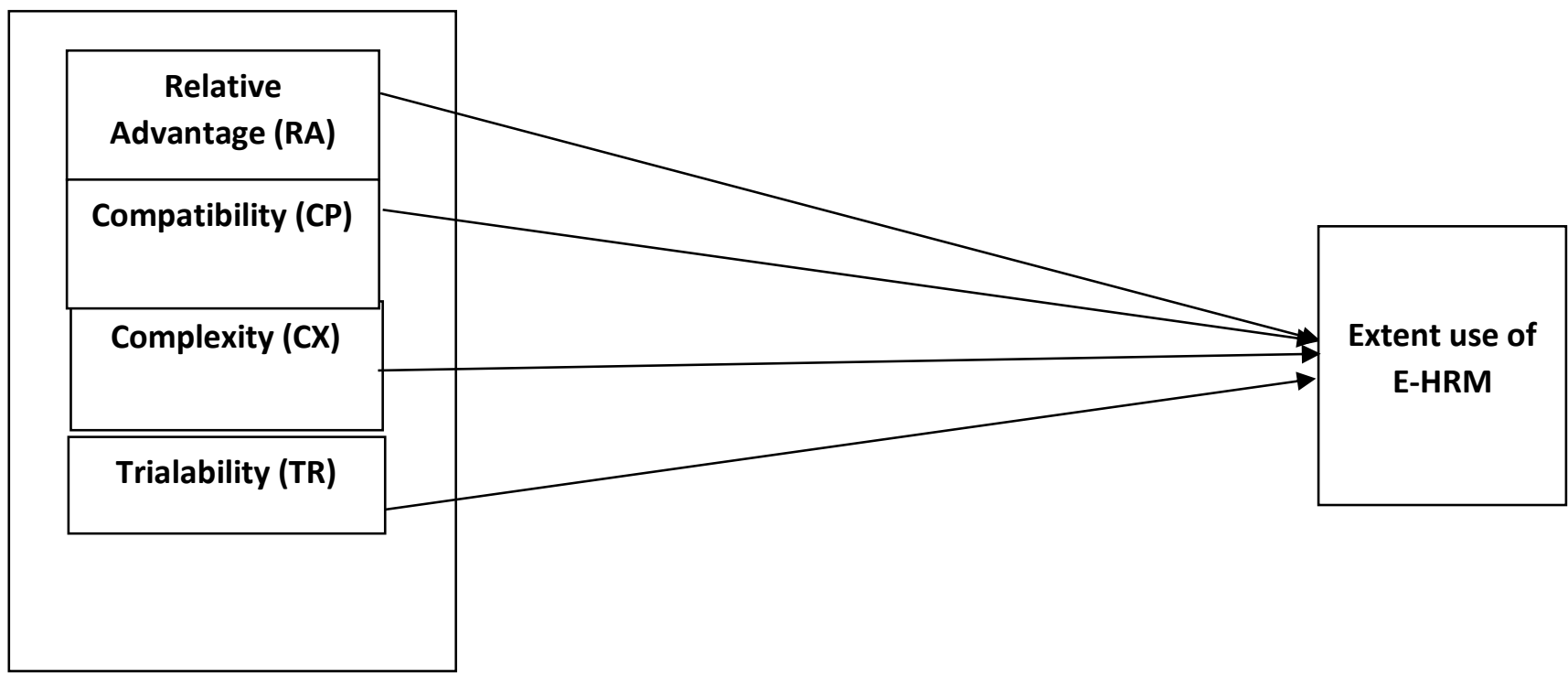

Figure (1)

Research Proposed Model

Research Variables

A-Independent variables:

Table (2): Independent variables

\begin{tabular}{|l|l|}
\hline Relative advantage & $\begin{array}{l}\text { (Rogers, 2003) defines relative advantage as the degree to which an } \\
\text { innovation is perceived to be better than the idea it supersedes. It can } \\
\text { also be viewed as the degree to which an innovation is perceived to } \\
\text { bring added benefits to the user. Hence, it is often measured in terms of } \\
\text { economic profitability, productivity improvement and other benefits. }\end{array}$ \\
\hline Compatibility & $\begin{array}{l}\text { (Rogers, 2003) states that compatibility is the degree to which an } \\
\text { innovation is perceived as consistent with the existing values, past } \\
\text { experiences and needs of potential adopters. }\end{array}$ \\
\hline Complexity & $\begin{array}{l}\text { (Rogers, 2003) defines complexity as the degree to which an innovation } \\
\text { is perceived as relatively difficult to understand and use. In the TAM } \\
\text { model, this attribute is referred to as perceived ease of use. }\end{array}$ \\
\hline Trialability & $\begin{array}{l}\text { According to (Rogers, 2003), trialability is the degree to which an } \\
\text { innovation may be experimented with on a limited basis. This trial is a } \\
\text { means to dispel uncertainty about adopting an innovation. }\end{array}$ \\
\hline
\end{tabular}

This framework of IT impact is developmental in that each stage but must be developed for the technology to be accessed or exploited. For the purpose of this study, the researcher has combined 
INTERNATIONAL JOURNAL OF ACADEMIC RESEARCH IN BUSINESS AND SOCIAL SCIENCES

Vol. 9, No. 3, March, 2019, E-ISSN: 222 2-6990 ¿ 2019 HRMARS

both theoretical perspectives to better understand the influence of various perceived attributes of innovations on the extent of use of E-HRM system.

\section{B- Dependent variables: Extent use of E-HRM}

Table (3) Dependent variable

\begin{tabular}{|l|l|}
\hline Extent use of E-HRM & $\begin{array}{l}\text { IT influences the work that HR professionals perform by focusing more } \\
\text { time and effort on activities related to IT support, such as maintaining } \\
\text { and developing IT-based HR applications. }\end{array}$ \\
\hline
\end{tabular}

Extensive use of IT impacts the HR professional job role through influencing information demands on these employees. In terms of impact, according to (Normalini et al, 2012), IT includes three stages of use which are automation, information and transformation. In the automation stage, IT is used primarily to automate manual systems and reduce the need of personnel to perform routine activities. According to (Normalini et al, 2012), IT automation often reduces the amount of routine work that must be done, potentially providing more opportunities for individuals to think and use their full cognitive capacities.

\section{Research Design}

This research has been designed to include two stages. The first stage is the exploratory study, the second stage is the questionnaire survey for the HR Department in ISP's companies in Egypt.

\section{Data Types and Sources Secondary Data}

The most important results of the previous studies that are related to the research variables from the books, dissertations, journals and internet websites.

\section{Primary Data}

In addition to the secondary data, the researcher depends on the collection of the primary data through questionnaire, this is in order to examine the research hypotheses and attain the pre-stated research objectives. This questionnaire is divided into two sections. The first one aims at analyzing companies' e-HR adoption and use and exploring associated benefits and obstacles. The second one is the personal data (demographic questions) which is kept to the end of the questionnaire to give the respondent time to develop some trust and confidence in the questionnaire.

\section{The Population}

Population refers to "the entire group of people, events or things of interest that the researcher wishes to investigate (Sekaran, 2003). The population of interest for this research is all the employees in the HR department in the internet service providers companies (ISPs) in Egypt. There are four Internet service providers (ISPS) in Egypt offering an ADSL service. Based on a preliminary investigation for the numbers of HR managers and employees in the (ISPs)in Egypt, the researcher found the population consisting only of 128 unit, so the researcher used census studies to represent 
INTERNATIONAL JOURNAL OF ACADEMIC RESEARCH IN BUSINESS AND SOCIAL SCIENCES

Vol. 9, No. 3, March, 2019, E-ISSN: 222 2-6990 ¿ 2019 HRMARS

each unit working in HR department of the four (ISPs)companies. Then an online questionnaire, developed and was electronically mailed to them.

\section{Results and Conclusion}

This sector presents the results of data analysis and the findings of the study. Collected data were analyzed using statistical package for social science (SPSS 20.0). The data analysis takes place in three steps after the sample results and descriptive statistics in addition to testing the Hypotheses of the Model Structure have been presented.

Population Results and Descriptive Statistics Table (4) Profile of the respondents

\begin{tabular}{|l|l|l|l|}
\hline Demographic variable & $\begin{array}{l}\text { Demographic } \\
\text { characteristics }\end{array}$ & Frequency & Percentage \\
\hline \multirow{3}{*}{ Gender } & Male & 89 & $69.5 \%$ \\
\cline { 2 - 4 } & Female & 39 & $30.5 \%$ \\
\hline \multirow{5}{*}{ Education } & Less than 25 & 12 & $9.4 \%$ \\
\cline { 2 - 4 } & 25up to 35 & 62 & $48.4 \%$ \\
\cline { 2 - 4 } & 36up to 45 & 53 & $41.4 \%$ \\
\hline \multirow{5}{*}{ Working experience } & Diploma & 19 & $14.8 \%$ \\
\cline { 2 - 4 } & Bachelor & 74 & $57.8 \%$ \\
\cline { 2 - 4 } & Master & 18 & $14.1 \%$ \\
\cline { 2 - 4 } & Others & 17 & $13.3 \%$ \\
\cline { 2 - 4 } & Less than 3 years & 14 & $10.9 \%$ \\
\cline { 2 - 4 } & 3up to 6 & 59 & $29.7 \%$ \\
\cline { 2 - 4 } & Gupto 10 & 38 & $10.2 \%$ \\
\cline { 2 - 4 } & Greater than 10 years & 13 & \\
\hline
\end{tabular}

\section{Normality Test}

Table (5) Skewness and Kurtosis for the study variables

\begin{tabular}{|l|l|l|l|l|l|l|}
\hline Variables & Mean & Std. & Skewness & S.E(S) & Kurtosis & S.E(K) \\
\hline $\begin{array}{l}\text { Extent use of E- } \\
\text { HRM }\end{array}$ & 34.7344 & 2.97889 & -.647 & 0.214 & .257 & .425 \\
\hline
\end{tabular}


INTERNATIONAL JOURNAL OF ACADEMIC RESEARCH IN BUSINESS AND SOCIAL SCIENCES

Vol. 9, No. 3, March, 2019, E-ISSN: 2222-6990 @ 2019 HRMARS

Reliability Test

Table (6) Results of the reliability test:

\begin{tabular}{|l|l|l|}
\hline Scale & Cronbach 's alpha & No.of items \\
\hline Relative advantage & .763 & 8 \\
\hline Complexity & .759 & 4 \\
\hline Trialability & .774 & 4 \\
\hline Compatibity & .725 & 5 \\
\hline Ease of use & .797 & 4 \\
\hline Usefulness of E-HRM & .859 & 4 \\
\hline
\end{tabular}

Test the Hypotheses of the Model Structure PRESENTING THE RESULTS FROM CORRELATION

The results using Pearson correlation could be presented in a research report as follows.

For hypotheses $\mathrm{H} .1$ which predicted that Perceived complexity has a strong negative impact on extent of E-HRM use. Regarding H.1 this result seems to be accepted for the following: The impact of the Complexity on extent use of E-HRM was investigated using Pearson product-moment correlation coefficient. Preliminary analyses were performed to ensure no violation of the assumptions of normality, linearity and homoscedasticity. There was a strong, positive correlation between the two variables except in Orange and Vodafone as follows: Where $r$ refers to the strength of correlation, $\mathbf{p}$ refers to confidence level, while $\mathbf{n}$ is the number of cases and $\mathbf{R}$ square is the amount of confidence.

\begin{tabular}{|l|l|l|l|l|}
\hline $\begin{array}{l}\text { Name of the } \\
\text { company }\end{array}$ & Orange & Vodafone & Etisalat & TEdata \\
\hline $\mathbf{r}$ & .40 & .10 & .53 & .61 \\
\hline $\mathbf{p}$ & $<.0005$ & $<.0005$ & $<.0005$ & $<.0005$ \\
\hline $\mathbf{n}$ & 30 & 35 & 35 & 28 \\
\hline $\mathbf{R}$ square & $16.48 \%$ & $100 \%$ & $28.72 \%$ & $38.31 \%$ \\
\hline
\end{tabular}

For hypotheses $\mathrm{H} .2$ which predicted that Perceived trialability has a strong positive impact on extent of E-HRM use. Regarding H.2 this result seems to be accepted for the following:

- The impact of Trailability on extent use of E-HRM was investigated using Pearson productmoment correlation coefficient. Preliminary analyses were performed to ensure no violation of the assumptions of normality, linearity and homoscedasticity. There was a strong, positive correlation between the two variables in Etisalat, but weak positive in Orange and TEdata, while weak negative correlation in Vodafone as follows: 
INTERNATIONAL JOURNAL OF ACADEMIC RESEARCH IN BUSINESS AND SOCIAL SCIENCES Vol. 9, No. 3, March, 2019, E-ISSN: 222 2-6990 @ 2019 HRMARS

\begin{tabular}{|l|l|l|l|l|}
\hline $\begin{array}{l}\text { Name of the } \\
\text { company }\end{array}$ & Orange & Vodafone & Etisalat & TEdata \\
\hline $\mathbf{r}$ & .20 & -.09 & .54 & .37 \\
\hline $\mathbf{p}$ & $<.0005$ & $<.0005$ & $<.0005$ & $<.0005$ \\
\hline $\mathbf{n}$ & 30 & 35 & 35 & 28 \\
\hline R square & $16.48 \%$ & $100 \%$ & $28.72 \%$ & $38.31 \%$ \\
\hline
\end{tabular}

For hypotheses $\boldsymbol{H . 3}$ which predicted that Perceived compatibility has a strong positive impact on extent of E-HRM use. Regarding H.3 this result seems to be accepted for the following:

- The impact of the Compatibility on extent use of E-HRM was investigated using Pearson product-moment correlation coefficient. Preliminary analyses were performed to ensure no violation of the assumptions of normality, linearity and homoscedasticity. There was a strong, positive correlation between the two variables in TEdata, but weak positive correlation in Orange, Etisalat and Vodafone as follows:

\begin{tabular}{|l|l|l|l|l|}
\hline $\begin{array}{l}\text { Name of the } \\
\text { company }\end{array}$ & Orange & Vodafone & Etisalat & TEdata \\
\hline $\mathbf{r}$ & .49 & .17 & .44 & .71 \\
\hline $\mathbf{p}$ & $<.0005$ & $<.0005$ & $<.0005$ & $<.0005$ \\
\hline $\mathbf{n}$ & 30 & 35 & 35 & 28 \\
\hline $\mathbf{R}$ square & $24.20 \%$ & $2.89 \%$ & $19.36 \%$ & $50.41 \%$ \\
\hline
\end{tabular}

For hypotheses $\mathrm{H.4}$ which predicted that Perceived relative advantage has a strong positive impact on extent of E-HRM use. Regarding H.4 this result seems to be accepted for the following:

The relationship between the relative advantage and extent use of E-HRM was investigated using Pearson product-moment correlation coefficient. Preliminary analyses were performed to ensure no violation of the assumptions of normality, linearity and homoscedasticity. There was a strong, positive correlation between the two variables in TEdata and Orange, but weak positive correlation in, Etisalat and Vodafone as follows:

\begin{tabular}{|l|l|l|l|l|}
\hline $\begin{array}{l}\text { Name of the } \\
\text { company }\end{array}$ & Orange & Vodafone & Etisalat & TEdata \\
\hline $\mathbf{r}$ & .62 & .09 & .37 & .56 \\
\hline $\mathbf{p}$ & $<.0005$ & $<.0005$ & $<.0005$ & $<.0005$ \\
\hline $\mathbf{n}$ & 30 & 35 & 35 & 28 \\
\hline $\mathbf{R}$ square & $38.44 \%$ & $0.82 \%$ & $13.69 \%$ & $32.14 \%$ \\
\hline
\end{tabular}

\section{Regression}

In addition to the correlation test, the researcher used multiple regressions to determine the contribution and the statistical significance of each independent variable.

Step 1: Checking the assumptions Multicollinearity: In this study, all variables are performed with the multicollinearity test and the results demonstrate the low intercorrelation between independent variables with all the VIF values less than 10 . 
INTERNATIONAL JOURNAL OF ACADEMIC RESEARCH IN BUSINESS AND SOCIAL SCIENCES

Vol. 9, No. 3, March, 2019, E-ISSN: 222 2-6990 @ 2019 HRMARS

Step 2: Evaluating the model :In this case, the value is.292 in Orange , .013 in Vodafone , .158 in Etisalat and .421 in Tedata Expressed as a percentage this means that our model explains 29 percent in Orange, $1 \%$ in Vodafone , $15 \%$ in Etisalat and $42 \%$ in Tedata of the variance in The Extent use of EHRM. This is quite a respectable result compared to some of the results reported in the journals!

\section{ANOVA}

The Sig. value of the independent sub-variable Complexity 000 which is less than 0.05 , the variable is making a significant unique contribution to the prediction of the dependent variable in Orange,Vodafone, Etisalat and Tedata. The Sig. value of the independent sub-variable Trailability 000 which is less than .0 .05 , the variable is making a significant unique contribution to the prediction of the dependent variable in Orange, Vodafone, Etisalat and Tedata. The Sig. value of the independent sub-variable Compatibility 000 which is less than .0 .05 , the variable is making a significant unique contribution to the prediction of the dependent variable in Orange,Vodafone , Etisalat and Tedata.

The Sig. value of the independent sub-variable Relative advantage 000 which is less than .0 .05 , the variable is making a significant unique contribution to the prediction of the dependent variable in Orange,Vodafone, Etisalat and Tedata.

Step 3: Evaluating each of the independent variables: To know the contribution of each independent variable; therefore the researcher used the beta values in the comparison.

In this case the largest beta coefficient is .620, which is for Relative advantage in Orange. The Beta value for Trailability was slightly lower .203, indicating that it made less of a unique contribution.

In this case the largest beta coefficient is .170, which is for Compatibility in Vodafone. The Beta value for Trailability was slightly lower -.094, indicating that it made less of a unique contribution.

In this study the largest beta coefficient is .954, which is for Compatibility in Etisalat. The Beta value for Relative advantage was slightly lower .370, indicating that it made less of a unique contribution. In this case the largest beta coefficient is .920, which is for Compatibility in Tedata. The Beta value for Trailability was slightly lower .376, indicating that it made less of a unique contribution.

This results can be summarized in the next table as follows:

\begin{tabular}{|l|l|l|l|l|}
\hline $\begin{array}{l}\text { Independent } \\
\text { variables }\end{array}$ & Orange & Vodafone & Etisalat & Tedata \\
\hline Complexity & .406 & .101 & .536 & .615 \\
\hline Trailability & .203 & -.094 & .548 & .376 \\
\hline Compatibility & .492 & .170 & .954 & .920 \\
\hline $\begin{array}{l}\text { Relative } \\
\text { advantage }\end{array}$ & .620 & .091 & .370 & .567 \\
\hline
\end{tabular}

\section{Results and Recommendations}

This sector highlights the main findings of the research in a cohesive manner. It reviews the research background and findings, followed by recommendations. It also concludes with future research ideas. The researcher comes up with the results that there is a significant impact of the IT determinants of 
adoption variables affecting the extent use of E-HRM. These variables differs from company to another according to their impact on the extent use of E-HRM.

1- For the First hypothesis: H1. Perceived Complexity has a strong negative impact on extent of E-HRM use. The results showed that there was a strong, positive correlation between the two variables except in Orange and Vodafone. And the largest contribution for the Complexity was in TEdata and its lowest contribution was in Vodafone.

2- For the second hypothesis: H2. Perceived Trialability has a strong positive impact on extent of E-HRM use. The results showed that there was a strong, positive correlation between the two variables in Etisalat, but weak positive in Orange and TEdata, while weak negative correlation in Vodafone. And the largest contribution for the Trialability was in Etisalat and its lowest contribution was in Vodafone.

3- For the third hypothesis: H3. Perceived Compatibility has a strong positive impact on extent of E-HRM use. The results showed that there was a strong, positive correlation between the two variables in TEdata, but weak positive correlation in Orange, Etisalat and Vodafone. And the largest contribution for the Compatibility was in Etasalat and its lowest contribution was in Vodafone.

4- For the fourth hypothesis: H4.Perceived Relative advantage has a strong positive impact on extent of E-HRM use. The results showed that there was a strong, positive correlation between the two variables in TEdata and Orange, but weak positive correlation in Etisalat and Vodafone. And the largest contribution for the Relative advantage was in Orange and its lowest contribution was in Vodafone.

\section{Recommendations}

Organizations should identify the strategic value and competitive advantage that they can gain through using E-HRM innovation. Organizations should come to an agreement with the vendor on EHRM features when they invest on E-HRM. Required subsystems need to be planned and ordered beforehand to avoid malfunctions due to incompatible infrastructure and higher upgrading cost.

Organizations would record high using efficiency and effectiveness if E-HRM aligns with information system strategy and HR strategy. Organizations need to integrate E-HRM functions with other business functions.

\section{Research Contribution}

On the academic level, the study provides a detailed outline of how some determinants have their impact on adopting new innovation (E-HRM technology) on the role of the HRM in Egyptian firms. Unfortunately, less attention has been paid to the impact of various determinants of attitudes towards using E-HRM. It has become increasingly important to gain a greater understanding of these determinants and their impacts on implementing new technology as E-HRM. (Tseng M.L et al, 2011). On the empirical level, this study is an attempt to fill this gap in IT and E-HRM literature especially in Egyptian firms by presenting a constructed model for accepting new technology E-HRM. 


\section{Research Limitations}

The suggested model discusses the impact of the IT determinants of the adoption of E-HRM as a particular type of technological innovation on HR professional employees in ISP's Egyptian firms which differs from other individuals working in other sectors in the same firms in other countries.

\section{Ideas for Future Research}

- The model of the study can be altered by removing the relative advantage variable -that make this a more media-oriented model - and adding different IT determinants of extent use to the model for more testing. Similarly, perceived risks could be presented as determinants on a risk-by-risk basis, rather than a combined approach.

- The model of the study may be used to understand the impact of the extent use of E-HRM in other developing countries.

\section{Acknowledgements}

I would like to express my deep gratitude and appreciation to my supervisor professor Dr.Kamel Omran for his assistance and support, and management style that gave me the space to work on my own and express myself freely, without his motivation the construction would not have been described.

\section{References}

- Aunger, R. (2010).Types of technology, Technological Forecasting \& Social Change. 77, 762782.

- Dahui, L., Patrick, Y.K. C., Slyke, C. V. (2010) A comparative study of individual acceptance of instant messaging in the US and China: A structural equation modeling approach. Communications of the association for Information system, 26 (1), 5.

- Jain, A. \& Goyal, A. (2014). E-Recruitment \& E-Human Resource Management Challenges in the Flat World: A Case Study of Indian. International Journal of Scientific and Research Publications, 4 (1), 2250-3153.

- Laumer, S., Eckhardt, A., Weitzel, T. (2010) Electronic human resource management in an ebusiness environment. J Elec Com Res .11(4), 240-50.

- Li-Hua, R. and Lu, L. (2013), Technology strategy and sustainability of business: Empirical experiences from Chinese cases. Journal of Technology Management in China, 8, (2), 62-82.

- Maatman, M. (2010). Measuring the effectiveness of e-HRM: the development of an analytical framework for the measurement of e-HRM and its application within a Dutch Ministry.

- Nagendra, A. \& Deshpande, M. (2013). Human Resource Information Systems (HRIS) in HR planning and development in mid to large sized organizations. Procedia-Social and Behavioral Sciences, 133 (14), $61-67$.

- Normalini, M. D., Kassim, T. \& Kurnia, R. S. (2012). Antecedents and outcomes of human resource information system (HRIS) use. International Journal of Productivity and Performance Management, 61 (6), $603-623$.

- Olivas-Lujan, M.R. \& Zapata-Cantu, J. R. (2007). e-HRM in Mexico: adapting innovations for global competitiveness. International Journal of Manpower, 28 (5), 418 - 434. 
- Panayotopoulou L., Vakola, M. \& Galanaki, E. (2007). E-HR adoption and the role of HRM: evidence from Greece, Personnel Review. 36 (2), 277 - 294.

- Rogers, E.M. (2003). Diffusion of innovations, 5th ed., The Free Press, New York, NY.

- Ruel, H., Bondarouk, T., \& Looise, J.K. (2004).E-HRM: innovation or irritation: an explorative empirical study in five large companies on web-based HRM. Man Rev, 15(3), 80-364.

- Sekaran, U. (2003). Research methods for business, fourth edition, John Wiely \& Sons, Inc.

- Stirpe, L. \& Bonache, J. \& Trullen, J. (2015). The acceptance of newly introduced HR practices. International Journal of Manpower. 36 (3), 334 - 353.

- Strohmeier, S. \& Kabst, R. (2009). Organizational adoption of e-HRM in Europe. Journal of Managerial Psychology, 24 (6), 482 - 501.

- Teo, T. S. H., Lim, G. S. \& Fedric, S. A. (2007). The adoption and diffusion of human resources information systems in Singapore. Asia Pacific Journal of Human Resources, 45(1), 44-62.

- Tseng, M.L., Lan, L.W., Wang, R., Chiu, A.S.F. \& Cheng, H.P. (2011). Using hybrid model to evaluate the green performance in uncertainty. Environmental Monitoring and Assessment, 175(1), 367-385.

- Ulrich, D. (1997). HR of the future: Conclusions and observations. Human Resource Management. 36, 175-179.

- Voermans, M. \& Veldhoven, M. (2007). Attitude towards E-HRM: an empirical study at Philips. Per Rev, 36(6), 887-902.

- Wahab, S. A., Rose, R. C. \& Osman, S. I. (2012). Defining the Concepts of Technology and Technology Transfer: A Literature Analysis. International Business Research, 5(1), 61-71. 
INTERNATIONAL JOURNAL OF ACADEMIC RESEARCH IN BUSINESS AND SOCIAL SCIENCES Vol. 9, No. 3, March, 2019, E-ISSN: 222 2-6990 @ 2019 HRMARS 